ISSN 1392-3196 / e-ISSN 2335-8947

Zemdirbyste-Agriculture, vol. 100, No. 3 (2013), p. 227-234

DOI 10.13080/z-a.2013.100.029

\title{
Stability of soil organic carbon in agro and forest ecosystems on Arenosol
}

\author{
Kęstutis ARMOLAITIS ${ }^{1,2}$, Jūratė ALEINIKOVIENE் $\dot{1}^{1}$, Jadvyga LUBYTE் ${ }^{3}$, Vilma ŽĖKAITE் ${ }^{2}$, \\ Paulius GARBARAVIČIUS ${ }^{1}$ \\ ${ }^{1}$ Institute of Forestry, Lithuanian Research Centre for Agriculture and Forestry \\ Liepu 1, Girionys, Kaunas distr., Lithuania \\ E-mail: k.armolaitis@mi.lt \\ ${ }^{2}$ Perloja Experimental Station, Lithuanian Research Centre for Agriculture and Forestry \\ Sodo 12, Perloja, Varèna distr., Lithuania \\ ${ }^{3}$ Agrochemical Research Laboratory, Lithuanian Research Centre for Agriculture and Forestry \\ Savanoriu 287, Kaunas, Lithuania
}

\begin{abstract}
The aim of the study was to assess the stability of soil organic carbon (SOC) in Arenosol (AR) under three different land uses: 1) continuous arable land, 2) abandoned for the last 15 years arable land, and 3) 50 years ago afforested with Scots pine (Pinus sylvestris L.) or silver birch (Betula pendula Roth) arable land. In the 0-10, 10-20 and 20$40 \mathrm{~cm}$ mineral soil layers the following was determined: 1) total SOC and humus fractional composition in bulk soil, 2) unprotected SOC (water extractable $\mathrm{SOC}$ and soil microbial biomass carbon $\left(\mathrm{C}_{\text {bio }}\right)$ ), and 3 ) in physical fractions unprotected and protected from microbial decomposition SOC. Mean $\mathrm{C}_{\mathrm{bio}}$ was the lowest in pine plantations, the highest in birch plantations and intermediate in arable or abandoned arable land. The highest concentrations of fulvic and humic acids and unprotected water extractable SOC were found in forest plantations. However, mineral topsoil after the afforestation, especially with birch, contained the highest concentrations of total SOC and the concentrations of SOC protected in soil organic matter (SOM) of silt + clay sized $(<53 \mu \mathrm{m})$ fraction.

Our results confirmed the Kyoto Protocol's provision that the afforestation of nutrient-poor sandy arable soils with birch could be relevant for soil carbon sequestration.
\end{abstract}

Key words: abandoned land, afforested land, arable land, unprotected and protected SOC.

\section{Introduction}

The global terrestrial pool of organic carbon $(\mathrm{OC})$ in soil organic matter (SOM) is almost three times as high as that in the plant biomass (Guggenberger, 2010). Therefore, the accumulation of soil organic carbon (SOC) has a global dimension in the mitigation of climate change (UNFCCC, 1998; IPCC 2003; 2006; 2007). Moreover, SOM, especially humus, predicts the productivity and the sustainability of agro and forest ecosystems (Franzmeier et al., 1985; Vaičys et al., 1997; Lal, 2009; Liaudanskienè et al., 2011). SOM consists of a complex of large and amorphous organic molecules and particles that are unprotected or physicochemically protected from microbial decomposition (Six et al., 2002). Therefore, various types of SOM have different turnover time: from $<10$ years (active SOM pools) to $>500$ years for $\mathrm{OC}$ resistant to the oxidation by $\mathrm{H}_{2} \mathrm{O}_{2}$ or $\mathrm{Na}_{2} \mathrm{~S}_{2} \mathrm{O}_{8}$ (von Lützow et al., 2007; Guggenberger, 2010).

Dissolved and water extractable SOC, soil microbial biomass $\mathrm{C}$, and $\mathrm{SOC}$ in light fraction (SOC not occluded in 53-250 $\mu \mathrm{m}$ sized microaggregates) reflect active SOC pool (Six et al., 2002; von Lützow et al., 2007). Meanwhile the silt and clay content and the microaggregation in mineral soils protect SOM from the microbial decomposition. In general, three main mechanisms of SOM stabilization have been defined: 1) physical protection (OC occluded/protected in 53-250 $\mu \mathrm{m}$ sized soil microaggregates), 2) chemical stabilization (OC associated with silt and clay), and 3) biochemical stabilization (OC biochemically protected in non-hydrolyzable SOM including stabile humus fractions) (Six et al., 2002). For example, the content of silt and clay protected $\mathrm{C}$ directly depends on silt and clay contents in the soil. Meanwhile the changes in land use or land management initially affect unprotected SOM. However, over the period of several decades conventional tillage can decrease, while the application of manure and mineral fertilizers increase the content of SOC that is physically and chemically protected (Six et al., 2002; Sleutel et al., 2006; Šlepetienè et al., 2008; Feiziene et al., 2011).

The abandonment of infertile arable sandy soils is apparent in Lithuania (Armolaitis et al., 2007). Such abandoned arable land could be afforested or maintained as perennial grassland. The objective of the current study 
was to assess the stability of SOC in Arenosol within three different arable land uses and managements: 1) continuous arable land, 2) abandonment, and 3) afforestation of arable land. Our research was based on the concept that the stabilization of SOC could be evaluated by the quantitative equilibrium/distribution of unprotected and protected SOC pools. We hypothesized that the stability of SOC could be: 1) diminished by conventional tillage and crop output in arable land, and 2) affected by litter accumulation/decomposition in afforested arable land.

\section{Materials and methods}

Site description and soils. The research was carried out in 2011 at the Perloja Experimental Station of Lithuanian Research Centre for Agriculture and Forestry situated in South Lithuania $\left(54^{\circ} 10^{\prime} \mathrm{N}, 24^{\circ} 25^{\prime} \mathrm{E}\right)$. Four study sites were selected within different uses of Arenosol (AR): in 1) arable land afforested with 50-year-old Scots pine (Pinus sylvestris L.) plantations, 2) abandoned for the last 15 years former arable land (both in Perloja experiment that has been described in detail by Armolaitis et al. (2007; 2011), and in 3) adjacent arable land afforested with 50-year-old silver birch (Betula pendula Roth) plantation and 4) adjacent arable land where continuous conventional tillage (mouldboard ploughing in autumn and presowing spring tine cultivation) was applied. In all treatments, the soils were well-drained Haplic Arenosol (ARh) (FAO/UN, 2006) developed on glaciofluvial sandy deposits from the last Riss-Wurm (Weichselian) glaciation. The depths of present or former ploughing Ap horizons were about $20 \mathrm{~cm}$. In non-fertilized forest plantations the soils could be characterized as forest Arenosol because they have permanent organic layer. Mean mass of soil organic layer comprised $54.8 \mathrm{t} \mathrm{ha}^{-1}$ in Scots pine plantations (stem volume $-340 \mathrm{~m}^{3} \mathrm{ha}^{-1}$ ) and $45.8 \mathrm{t} \mathrm{ha}^{-1}$ in silver birch plantation (stem volume $\left.-135 \mathrm{~m}^{3} \mathrm{ha}^{-1}\right)$. Meanwhile, the mass of soil organic layer (mainly annual litter of grasses) did not exceed $5 \mathrm{t} \mathrm{ha}^{-1}$ in perennial grassland of abandoned arable land. Besides, it was found that the former Ap horizon had been renaturalized according to the increase of acidity in pine plantations and due to the leaching of nutrients in abandoned land (Armolaitis et al., 2011). The crops of winter or spring wheat were cultivated for the declaration of crops in arable land.

The mean annual temperature in the study area (1961-1990) was $6.1^{\circ} \mathrm{C}$, with the mean January temperature of $-5.8^{\circ} \mathrm{C}$ and mean July temperature of $16.9^{\circ} \mathrm{C}$, while mean annual precipitation amounted to about $640 \mathrm{~mm}$.

Soil sampling and analyses. In 2011, the sampling was carried out in the end of August. Composite soil samples (each at 6 systematically distributed points) were collected from the $0-10,10-20$ and 20$40 \mathrm{~cm}$ deep mineral layers in three replicates along the $100-\mathrm{m}$ transects in each treatment. For the general characterization of the studied Arenosol the following was estimated: fine $(<2 \mathrm{~mm})$ soil bulk density - according to ISO 11272:1998; soil texture - ISO 11277:2009; $\mathrm{pH}_{\mathrm{CaCl} 2}$ - LST ISO 10390:2005; concentrations of total soil organic carbon (SOC) - ISO 10694:1995; and total nitrogen $(\mathrm{N})$ was analyzed using the Kjeldahl method (ISO 11261:1995). As unprotected SOC the concentration of water extractable organic carbon (OC), the concentrations of carbon (C) in soil microbial biomass and humus fractional composition were determined.
Hot water extractable SOC, which is used as a measure for potentially bioavailable soil organic matter (SOM), was determined according to Schulz et al. (1991). For determination of humus fractional composition (fulvic and humic acids) the method described in Faithfull (2002) was applied.

Soil microbial biomass carbon $\left(C_{b i}\right)$ and nitrogen $\left(N_{b i o}\right)$. For estimation of soil $\mathrm{C}_{\text {bio }}$ and $\mathrm{N}_{\text {bio }}$ in the 0-10 and $10-20 \mathrm{~cm}$ deep mineral layers the chloroform fumigation-extraction method ISO/DIS 14240-2:1997 was used (Vance et al., 1987). Non-fumigated soil samples ( $20.0 \mathrm{~g}$ field moisture soil) were extracted with $80 \mathrm{ml}$ of $0.5 \mathrm{M} \mathrm{K}_{2} \mathrm{SO}_{4}$ by shaking for $30 \mathrm{~min}$ and the suspension filtered using a Whatman No. 2 filter paper. Jointly, soil samples were fumigated by exposing soil to alcohol-free $\mathrm{CHCl}_{3}$ vapour for $24 \mathrm{~h}$ in a vacuum desiccator. After $\mathrm{CHCl}_{3}$ was removed by vacuum extraction, the fumigated soils were extracted with $\mathrm{K}_{2} \mathrm{SO}_{4}$ as in the non-fumigated soil samples treatment. Soil $\mathrm{C}_{\text {bio }}$ of the non-fumigated and fumigated soil extracts was analyzed using the digestion-titration method. After the transferring $10 \mathrm{ml}$ of extracts to a test tube, $5 \mathrm{ml}$ of $33 \mathrm{mM} \mathrm{K}_{2} \mathrm{Cr}_{2} \mathrm{O}_{7}$ and $5 \mathrm{ml}$ of concentrated $\mathrm{H}_{2} \mathrm{~S}_{4}$ were added. The samples were digested for $10 \mathrm{~min}$ at $175^{\circ} \mathrm{C}$ and titrated using 0.05 $\mathrm{M} \mathrm{FeSO}_{4}$ with 1.10-phenanthrobine ferrous sulfate as the indicator. The concentration of soil $\mathrm{C}_{\mathrm{bio}}\left(\mu \mathrm{g} \mathrm{g}^{-1} \mathrm{C}\right.$ soil dry matter (DM)) was calculated according to Vance et al. (1987) taking the $\mathrm{K}_{2} \mathrm{SO}_{4}$ extract efficiency factor 0.38 for $\mathrm{C}_{\text {bio }}$. For $\mathrm{N}_{\text {bio }}$ estimation $8 \mathrm{ml}$ of the non-fumigated and fumigated soil sample filtrates with $0.5 \mathrm{M} \mathrm{K}_{2} \mathrm{SO}_{4}$ were taken and treated with saturated boric acid $\left(\mathrm{H}_{3} \mathrm{BO}_{3}\right)$ and with the indicator (1.10-phenanthroline), then titrated using $0.01 \mathrm{M}$ sulfuric acid $\left(\mathrm{H}_{2} \mathrm{SO}_{4}\right)$. The concentration of soil $\mathrm{N}_{\text {bio }}$ ( $\mu \mathrm{g} \mathrm{g}^{-1} \mathrm{~N}$ soil $\left.\mathrm{DM}\right)$ was calculated according to Brookes et al. (1985) taking the $\mathrm{K}_{2} \mathrm{SO}_{4}$ extract efficiency factor 0.54 for $\mathrm{N}_{\text {bio }}$.

Soil organic carbon (SOC) in fractions of mineral soil. For the determination of protected SOC, physical and chemical fractionation was carried out in triplicate according to the procedure described in detail by Sleutel et al. (2006). As could be seen from Figure 1, wet sieving method using the 250 and $53 \mu \mathrm{m}$ sieves allowed us to collect: 1) $>250 \mu \mathrm{m}$ fraction - coarse free particulate organic matter ( $\mathrm{FPOM}$ ) and coarse sand - that contain unprotected SOC, 2) microaggregates $(53-250 \mu \mathrm{m})$ - fine fPOM and fine sand, and 3 ) water + soil $<53 \mu \mathrm{m}$ fraction. In the second step of physical fractionation, fine PPOM was isolated from the fine sand by density flotation with $1.85 \mathrm{~g} \mathrm{~cm}^{-3}$ sodium polytungstate and the centrifugation $\left(1250 \times \mathrm{g}\right.$ for $60 \mathrm{~min}$ at $\left.20^{\circ} \mathrm{C}\right)$. Consequently within the 53-250 $\mu \mathrm{m}$ the following fractions were separated: light (floating fine fPOM that contains unprotected SOC) and heavy. In addition, heavy fraction was dispersed in sodium hexametaphosphate $\left(5 \mathrm{~g} \mathrm{~L}^{-1}\right)$, and physically protected SOC in intra-microaggregate $\operatorname{POM}(>53 \mu \mathrm{m})$ and silt + clay sized $<53 \mu \mathrm{m}$ fraction were divided by shaking $18 \mathrm{~h}$ on shaker "Gerhardt LS 20" (Labexchange Die Laborgerätebörse GmbH, Germany). After chemical fractionation (hydrolysis technique with $6 \mathrm{M} \mathrm{HCl}$ ) the $<53 \mu \mathrm{m}$ fractions were separated into two silt + clay protected organic matter (OM) that contained: 1) SOC which is chemically stabilized, and 2) biochemically stabilized SOC. All obtained fractions were dried at $105^{\circ} \mathrm{C}$ and weighed, and analyzed for total SOC using CNS-analyzer "Elementar Vario EL Cube" (Elementar Analysensysteme $\mathrm{GmbH}$, Germany) as they contain no carbonate $\left(\mathrm{CaCO}_{3}\right)$. 


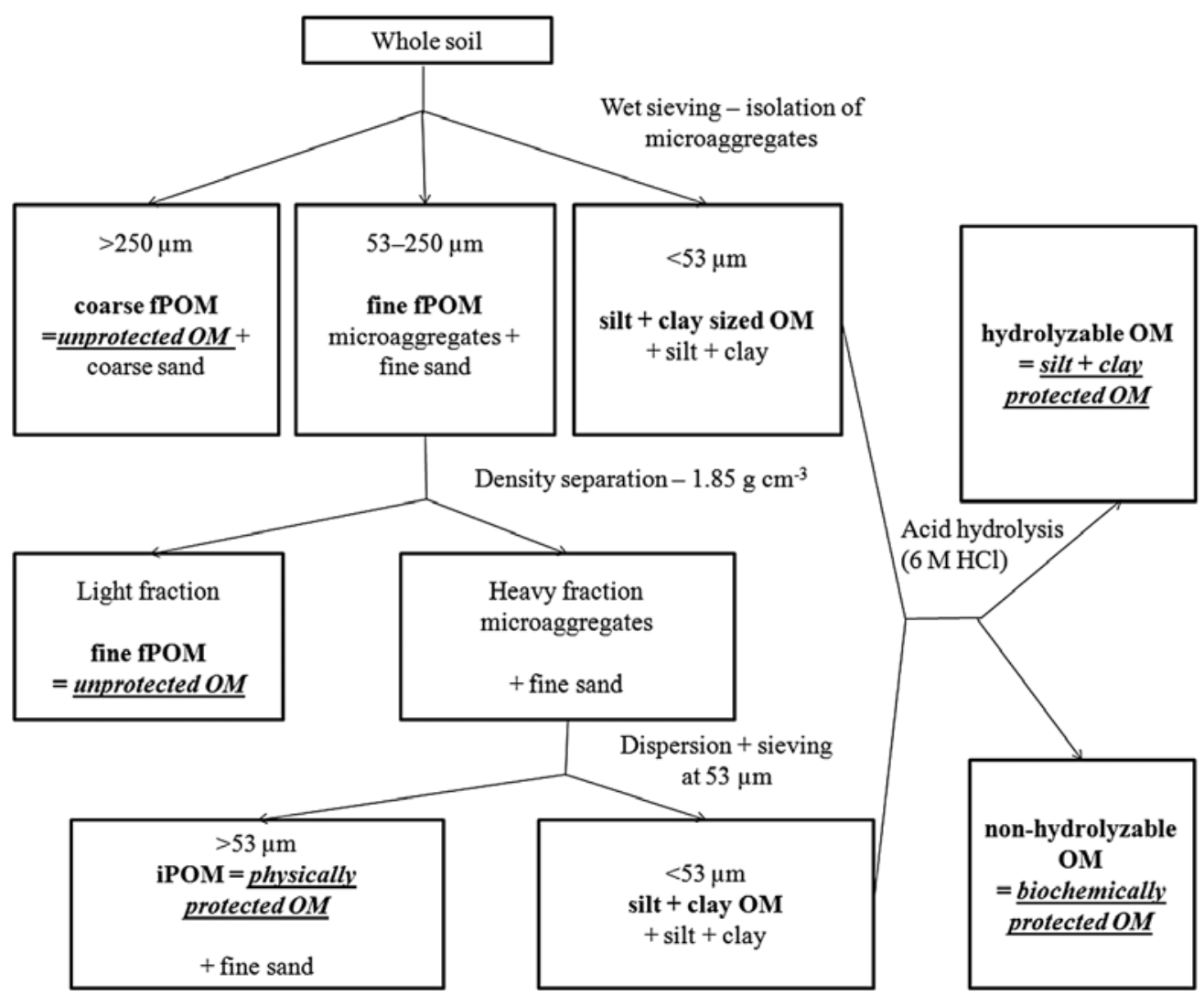

Figure 1. The scheme of the applied physical fractionation procedure for isolation of course free particulate organic matter (course PPOM), fine free POM (fine PPOM), intra-microaggregate POM (iPOM) and silt and clay sized organic matter (OM), with indication of the three isolated conceptual soil organic matter (SOM) pools according to the model of Six et al. (2002): unprotected OM, physically protected OM and silt and clay protected OM (from Sleutel et al., 2006)

The data was analyzed using the computer software Microsoft Excel (2003) and statistical software $S A S$ (2002). Significant differences $(P<0.05)$ in the contrasting factors were statistically evaluated by $A N O V A$. The STEPDISC SAS procedure was applied to select factors contributing most to the differentiation.

\section{Results and discussion}

The main characteristics of studied Arenosol and total soil organic carbon (SOC) content. Table 1 shows that there was little variability in soil texture among different land uses. Surface 0-10, 10-20 and 20$40 \mathrm{~cm}$ deep mineral layers of studied Arenosol mainly consisted of coarse sand (72-80\%) and fine silt (8-22\%) with the low clay content (4-6\%). Soil bulk density was slightly higher $(P<0.05)$ in mineral topsoil $(0-20 \mathrm{~cm})$ of arable land. Total $\mathrm{N}$ concentrations varied among the studied land uses insignificantly although the lowest $\mathrm{N}$ contents in arable land demonstrated that no fertilizers were applied there. However, it should be noted that mineral topsoil $(0-10 \mathrm{~cm})$ was by $0.4-0.6 \mathrm{pH}_{\mathrm{CaCl} 2}$ units

Table 1. The mean characteristics of surface mineral layers in studied Arenosol

\begin{tabular}{|c|c|c|c|c|c|c|c|}
\hline \multirow{2}{*}{ Land use } & \multicolumn{3}{|c|}{ Soil texture $\%$} & \multirow{2}{*}{$\begin{array}{l}\text { Soil bulk density } \\
\mathrm{Mg} \mathrm{m}^{-3}\end{array}$} & \multirow{2}{*}{$\mathrm{pH}_{\mathrm{CaCl} 2}$} & \multirow{2}{*}{$\begin{array}{c}\text { Total SOC } \\
\mathrm{g} \mathrm{kg}^{-1}\end{array}$} & \multirow{2}{*}{$\begin{array}{c}\text { Total N } \\
\mathrm{g} \mathrm{kg}^{-1}\end{array}$} \\
\hline & sand & silt & clay & & & & \\
\hline \multicolumn{8}{|c|}{$0-10 \mathrm{~cm}$} \\
\hline Arable & 76 & 19 & 5 & $1.43 \pm 0.05$ & $5.0 \pm 0.0$ & $7.52 \pm 1.13$ & $0.58 \pm 0.11$ \\
\hline Abandoned & 86 & 10 & 4 & $1.29 \pm 0.04$ & $5.1 \pm 0.1$ & $8.60 \pm 0.80$ & $0.91 \pm 0.29$ \\
\hline Scots pine & 80 & 14 & 6 & $1.23 \pm 0.05$ & $4.5 \pm 0.1$ & $11.06 \pm 0.12$ & $0.71 \pm 0.07$ \\
\hline Silver birch & 72 & 22 & 6 & $1.29 \pm 0.04$ & $4.6 \pm 0.1$ & $14.68 \pm 1.22$ & $0.90 \pm 0.13$ \\
\hline \multicolumn{8}{|c|}{$10-20 \mathrm{~cm}$} \\
\hline Arable & 83 & 12 & 5 & $1.55 \pm 0.03$ & $5.1 \pm 0.1$ & $7.30 \pm 0.86$ & $0.67 \pm 0.07$ \\
\hline Abandoned & 88 & 8 & 4 & $1.39 \pm 0.03$ & $5.1 \pm 0.2$ & $6.47 \pm 0.27$ & $0.80 \pm 0.28$ \\
\hline Scots pine & 81 & 13 & 6 & $1.39 \pm 0.03$ & $4.8 \pm 0.1$ & $6.34 \pm 0.47$ & $0.58 \pm 0.16$ \\
\hline Silver birch & 76 & 18 & 6 & $1.40 \pm 0.05$ & $4.8 \pm 0.1$ & $8.52 \pm 0.64$ & $0.62 \pm 0.23$ \\
\hline \multicolumn{8}{|c|}{$20-40 \mathrm{~cm}$} \\
\hline Arable & 76 & 18 & 6 & $1.60 \pm 0.06$ & $5.2 \pm 0.2$ & $2.15 \pm 0.34$ & $0.19 \pm 0.03$ \\
\hline Abandoned & 83 & 12 & 5 & $1.54 \pm 0.01$ & $5.7 \pm 0.1$ & $1.56 \pm 0.31$ & $0.26 \pm 0.19$ \\
\hline Scots pine & 80 & 14 & 6 & $1.39 \pm 0.02$ & $4.9 \pm 0.1$ & $2.63 \pm 0.94$ & $0.36 \pm 0.18$ \\
\hline Silver birch & 75 & 19 & 6 & $1.52 \pm 0.05$ & $4.8 \pm 0.1$ & $2.46 \pm 0.12$ & $0.18 \pm 0.06$ \\
\hline
\end{tabular}

Notes. SOC - soil organic carbon. Means or means \pm SD are given in the table. Significantly $(P<0.05)$ outstanding parameters are shown in bold. 
more acid and contained higher mean concentrations of total SOC in afforested arable land (by $30-50 \%$ in pine, and by $1.7-2.0$ times in birch plantations) than in arable or abandoned arable land.

\section{Unprotected SOC: humus fractional} composition and water extractable SOC. The contents of non-extractable residue exceeded $99 \%$ and varied in a narrow interval of $99.02-99.83 \%$ (Table 2). However, the concentrations of humic acid and "aggressive" fulvic acid (that are mobile/free or weakly bound with/in clay minerals) were higher in afforested land. In forest plantations, the concentrations of fulvic acids were higher on average by 2.5 times and the concentrations of humic acids by $1.5-2.0$ times in the $0-10 \mathrm{~cm}$ mineral layer than in arable or abandoned arable land. Moreover, in pine plantations the concentrations of humic acids were higher (from $40 \%$ to 2.7 times) in deeper, $10-20$ and $20-40 \mathrm{~cm}$, mineral layers.

Table 2. Humus fractional composition and concentrations of water extractable soil organic carbon (SOC) in surface mineral layers of studied Arenosol

\begin{tabular}{|c|c|c|c|c|c|}
\hline \multirow{2}{*}{$\begin{array}{l}\text { Depth of } \\
\text { mineral layer }\end{array}$} & \multirow[b]{2}{*}{ Land use } & \multicolumn{3}{|c|}{ Humus fractional composition $\%$} & \multirow{2}{*}{$\begin{array}{c}\text { Water extractable SOC } \\
\mathrm{mg} \mathrm{kg}^{-1}\end{array}$} \\
\hline & & fulvic acids & humic acids & $\begin{array}{c}\text { non-extractable } \\
\text { residue }\end{array}$ & \\
\hline \multirow{4}{*}{$0-10 \mathrm{~cm}$} & arable & $0.11 \pm 0.02$ & $0.36 \pm 0.04$ & $99.53 \pm 0.05$ & $277 \pm 16$ \\
\hline & abandoned & $0.11 \pm 0.01$ & $0.44 \pm 0.09$ & $99.45 \pm 0.10$ & $398 \pm 32$ \\
\hline & Scots pine & $0.26 \pm 0.01$ & $0.72 \pm 0.04$ & $99.02 \pm 0.04$ & $633 \pm 32$ \\
\hline & silver birch & $0.28 \pm 0.02$ & $0.66 \pm 0.06$ & $99.06 \pm 0.03$ & $657 \pm 6$ \\
\hline \multirow{4}{*}{$10-20 \mathrm{~cm}$} & arable & $0.13 \pm 0.02$ & $0.34 \pm 0.04$ & $99.53 \pm 0.05$ & $183 \pm 16$ \\
\hline & abandoned & $0.08 \pm 0.00$ & $0.30 \pm 0.04$ & $99.62 \pm 0.04$ & $284 \pm 20$ \\
\hline & Scots pine & $0.10 \pm 0.01$ & $0.48 \pm 0.02$ & $99.42 \pm 0.03$ & $297 \pm 40$ \\
\hline & silver birch & $0.14 \pm 0.00$ & $0.40 \pm 0.08$ & $99.46 \pm 0.08$ & $220 \pm 20$ \\
\hline \multirow{4}{*}{$20-40 \mathrm{~cm}$} & arable & $0.04 \pm 0.00$ & $0.14 \pm 0.05$ & $99.82 \pm 0.04$ & $99 \pm 14$ \\
\hline & abandoned & $0.06 \pm 0.00$ & $0.11 \pm 0.00$ & $99.83 \pm 0.00$ & $106 \pm 21$ \\
\hline & Scots pine & $0.04 \pm 0.01$ & $0.30 \pm 0.03$ & $99.66 \pm 0.03$ & $52 \pm 16$ \\
\hline & silver birch & $0.05 \pm 0.00$ & $0.18 \pm 0.02$ & $99.77 \pm 0.02$ & $48 \pm 12$ \\
\hline
\end{tabular}

Notes. Means $\pm \mathrm{SD}$ are given in the table. Significantly $(P<0.05)$ outstanding parameters are shown in bold.

Average concentrations of water extractable SOC significantly $(P<0.05)$ differed only between agro and forest ecosystems (Table 2). The largest differences were found in mineral topsoil $(0-10 \mathrm{~cm})$ and in the deepest (20-40 cm) studied mineral layer. In mineral topsoil, the mean concentrations of water extractable SOC was 1.62.4 times higher in pine and birch plantations, while in the $20-40 \mathrm{~cm}$ layer, in contrast, it was two times higher in the arable land and abandoned arable land. In the first case, the decomposition of soil organic horizons could affect the higher concentrations of water extractable SOC in pine plantations, while in the second case, could be influenced by the higher soil moisture in arable land and abandoned arable land (Ellerbrock et al., 2005).

Concentrations of soil microbial biomass carbon $\left(C_{b i o}\right)$ and soil microbial biomass nitrogen $\left(N_{b i o}\right)$. The mean $\mathrm{C}$ concentrations in soil $\mathrm{C}_{\text {bio }}$ in mineral surface 0-10 and 10-20 cm layers of studied Arenosol ranged from 19.8 to $104.6 \mu \mathrm{g} \mathrm{g}^{-1} \mathrm{C}$ (Table 3). The lowest concentrations of $\mathrm{C}_{\mathrm{bio}}$ were estimated in pine plantations, whereas mineral $0-20 \mathrm{~cm}$ soil layer in birch plantations contained on average by $1.8-1.9$ and 3-4 times higher concentrations of $\mathrm{C}_{\mathrm{bio}}$ than in pine plantations and in arable or in abandoned arable lands, respectively. Moreover, the mean concentrations of $\mathrm{C}_{\mathrm{bio}}$ in arable and in abandoned arable land differed insignificantly $(P>0.05)$.

Table 3. The mean microbial biomass carbon $\left(\mathrm{C}_{\mathrm{bio}}\right)$ concentrations $\left(\mu \mathrm{g} \mathrm{g}^{-1} \mathrm{C}\right)$ in studied Arenosol

\begin{tabular}{ccc}
\hline \multirow{2}{*}{ Land use } & \multicolumn{2}{c}{ Mineral soil layers } \\
\cline { 2 - 3 } & $0-10 \mathrm{~cm}$ & $10-20 \mathrm{~cm}$ \\
\hline Arable & $56.0 \pm 3.0 \mathrm{~b}$ & $48.2 \pm 3.2 \mathrm{~b}$ \\
Abandoned & $58.8 \pm 3.2 \mathrm{~b}$ & $47.5 \pm 1.7 \mathrm{~b}$ \\
Scots pine & $33.1 \pm 2.1 \mathrm{a}$ & $19.8 \pm 0.8 \mathrm{a}$ \\
Silver birch & $104.6 \pm 4.1 \mathrm{c}$ & $88.1 \pm 2.0 \mathrm{c}$ \\
\hline
\end{tabular}

Notes. Standard errors of the means $(\mathrm{n}=9)$ are given in the table. Different letters indicate the significant differences $(P<$ 0.05 ) between the studied treatments.
Mean $\mathrm{N}$ concentrations in soil $\mathrm{N}_{\text {bio }}$ ranged from 2.7 to $13.1 \mu \mathrm{g} \mathrm{g}^{-1} \mathrm{~N}$ (Table 4 ) and were the lowest in mineral surface $0-10$ and $10-20 \mathrm{~cm}$ layers in pine plantations, whereas in birch plantations mean $\mathrm{N}_{\text {bio }}$ concentrations were, respectively, by 1.5-1.9 and 3-4 times higher than in not afforested land and in pine plantations. Thus, soil microbiota in arable and in abandoned arable land similarly $(P>0.05)$ accumulated nitrogen.

Table 4. The mean microbial biomass nitrogen $\left(\mathrm{N}_{\text {bio }}\right)$ concentrations $\left(\mu \mathrm{g} \mathrm{g}^{-1} \mathrm{~N}\right)$ in studied Arenosol

\begin{tabular}{ccc}
\hline \multirow{2}{*}{ Land use } & \multicolumn{2}{c}{ Mineral soil layers } \\
\cline { 2 - 3 } & $0-10 \mathrm{~cm}$ & $10-20 \mathrm{~cm}$ \\
\hline Arable & $8.5 \pm 0.5 \mathrm{~b}$ & $6.0 \pm 0.4 \mathrm{~b}$ \\
Abandoned & $8.2 \pm 0.7 \mathrm{~b}$ & $7.3 \pm 0.4 \mathrm{c}$ \\
Scots pine & $4.6 \pm 0.2 \mathrm{a}$ & $2.7 \pm 0.2 \mathrm{a}$ \\
Silver birch & $13.1 \pm 0.5 \mathrm{c}$ & $11.6 \pm 0.3 \mathrm{~d}$ \\
\hline
\end{tabular}

Explanations under Table 3

The obtained data on the concentrations of $\mathrm{C}_{\mathrm{bio}}$ were similar to those reported in other studies (Vance etal., 1987; Scharenbroch et al., 2005). It was estimated that the concentration of $\mathrm{C}_{\text {bio }}$ ranged from 49 to $465 \mu \mathrm{g} \mathrm{g}^{-1} \mathrm{C}$ and on average was $230 \mu \mathrm{g} \mathrm{g}^{-1} \mathrm{C}$. However, there is evidence that in forest soils the concentration of $\mathrm{C}_{\text {bio }}$ can even reach $910 \mu \mathrm{g} \mathrm{g}^{-1} \mathrm{C}$ (Bauhus et al., 1998). Meanwhile, in agricultural soils the concentrations of $\mathrm{C}_{\mathrm{bio}}$ are significantly higher and can comprise more than $1500 \mathrm{\mu g} \mathrm{g}^{-1} \mathrm{C}$ (Kalbitz et al., 2003). In contrast, the concentrations of $\mathrm{N}_{\text {bio }}$ in studied Arenosol were on average almost 10 times lower than those reported by Diaz-Ravina et al. (1988). It was indicated that the concentrations of $\mathrm{N}_{\text {bio }}$ ranged from 52 to $240 \mu \mathrm{g} \mathrm{g}^{-1}$ $\mathrm{N}$ and were highly dependent on climatic conditions and, especially, on soil type and land use specificity (Anderson, Domsch, 1989; Schimel et al., 1994). According to the data obtained in this work, it could be concluded that $\mathrm{C}$ and, especially, $\mathrm{N}$ concentrations in soil microbiota 
biomass were comparatively low. This indicates that SOM in studied Arenosol was intensively decomposing by the microbiota.

SOC distribution in the isolated mineral soil fractions. Table 5 summarizes the distribution (proportion in \%) of mineral soil DM over the various isolated soil fractions. It is not surprising that in studied sandy Arenosol the $>250 \mu \mathrm{m}$ fraction (coarse sand + course
fPOM) and the $>53 \mu \mathrm{m}$ physically protected $\mathrm{OM}$ in $53-250 \mu \mathrm{m}$ sized microaggregates amounted to $45-65 \%$ and $28-46 \%$ of bulk soil DM, respectively. Silt + clay sized fraction $(<53 \mu \mathrm{m}, \mathrm{OM}$ occluded and not occluded in microaggregates) comprised almost all remained part of whole soil, while light fraction (fine fPOM) in general (with the exception in $0-10 \mathrm{~cm}$ layer in pine plantations) did not exceed $1 \%$ of bulk soil DM.

Table 5. The distribution (\%) of the soil dry matter over the various isolated soil fractions in surface mineral layers of studied Arenosol

\begin{tabular}{|c|c|c|c|c|c|}
\hline \multirow{3}{*}{ Land use } & \multirow{3}{*}{$\begin{array}{c}\text { Coarse sand }+ \\
\text { coarse fPOM } \\
(>250 \mu \mathrm{m})\end{array}$} & \multicolumn{3}{|c|}{ Microaggregates + fine fPOM + fine sand $(53-250 \mu \mathrm{m})$} & \multirow{3}{*}{$\begin{array}{l}\text { Silt + clay } \\
(<53 \mu \mathrm{m})\end{array}$} \\
\hline & & \multirow{2}{*}{$\begin{array}{l}\text { light fraction } \\
\text { (fine fPOM) }\end{array}$} & \multicolumn{2}{|c|}{ heavy fraction } & \\
\hline & & & $>53 \mu \mathrm{m}$ & $<53 \mu \mathrm{m}$ & \\
\hline \multicolumn{6}{|c|}{$0-10 \mathrm{~cm}$} \\
\hline Arable & $54.6 \pm 1.3$ & $0.45 \pm 0.10$ & $33.0 \pm 3.5$ & $8.5 \pm 3.3$ & $3.9 \pm 0.5$ \\
\hline Abandoned & $45.5 \pm 5.8$ & $0.84 \pm 0.06$ & $44.8 \pm 2.5$ & $4.0 \pm 1.8$ & $2.7 \pm 0.4$ \\
\hline Scots pine & $46.8 \pm 2.1$ & $1.74 \pm 0.04$ & $41.4 \pm 1.6$ & $6.2 \pm 2.3$ & $5.6 \pm 0.3$ \\
\hline Silver birch & $55.1 \pm 5.4$ & $0.65 \pm 0.10$ & $32.4 \pm 3.4$ & $6.3 \pm 1.1$ & $6.4 \pm 0.8$ \\
\hline \multicolumn{6}{|c|}{$10-20 \mathrm{~cm}$} \\
\hline Arable & $54.0 \pm 0.8$ & $0.42 \pm 0.05$ & $33.4 \pm 0.5$ & $8.3 \pm 1.1$ & $3.8 \pm 0.1$ \\
\hline Abandoned & $46.0 \pm 0.8$ & $0.45 \pm 0.05$ & $43.3 \pm 2.9$ & $5.3 \pm 0.4$ & $4.0 \pm 0.4$ \\
\hline Scots pine & $47.9 \pm 3.0$ & $0.66 \pm 0.10$ & $46.3 \pm 6.4$ & $3.3 \pm 2.4$ & $5.1 \pm 0.6$ \\
\hline Silver birch & $50.8 \pm 2.1$ & $\mathbf{0 . 1 0} \pm \mathbf{0 . 0 3}$ & $34.9 \pm 1.9$ & $8.2 \pm 1.8$ & $5.7 \pm 0.3$ \\
\hline \multicolumn{6}{|c|}{$20-40 \mathrm{~cm}$} \\
\hline Arable & $65.1 \pm 12.1$ & $0.15 \pm 0.02$ & $27.6 \pm 10.5$ & $5.1 \pm 1.2$ & $1.9 \pm 0.7$ \\
\hline Abandoned & $50.5 \pm 7.1$ & $0.10 \pm 0.01$ & $37.9 \pm 5.7$ & $4.4 \pm 1.8$ & $1.3 \pm 0.2$ \\
\hline Scots pine & $44.8 \pm 8.2$ & $0.30 \pm 0.03$ & $43.7 \pm 7.0$ & $6.9 \pm 1.6$ & $3.9 \pm 0.6$ \\
\hline Silver birch & $53.1 \pm 4.0$ & $0.09 \pm 0.01$ & $36.1 \pm 3.4$ & $6.1 \pm 0.9$ & $3.7 \pm 0.3$ \\
\hline
\end{tabular}

Notes. $\mathrm{PPOM}$ - free particulate organic matter. Means $\pm \mathrm{SD}$ are given in the table. Significantly $(P<0.05)$ outstanding parameters are shown in bold.

There were some notable effects of studied land uses on soil DM proportion in studied soil fractions (Table 5). In arable land Ap horizon (0-20 cm) contained slightly higher proportion of coarse $(>250 \mu \mathrm{m})$ fraction, while in afforested land whole studied $0-40 \mathrm{~cm}$ soil mineral layer contained from 1.3-1.6 $(0-20 \mathrm{~cm})$ up to $2-3$ times $(20-40 \mathrm{~cm})$ larger silt + clay $(<53 \mu \mathrm{m})$ fraction obtained after wet sieving. Moreover, it should be pointed out that in afforested with pine land the proportion of light fraction was on average by $2-4$-fold higher than in arable land, while such effect was not determined in birch plantations.
The concentrations of SOC $\left(\mathrm{g} \mathrm{kg}^{-1}\right)$ in different size and density fractions of Arenosol are shown in Table 6 . It could be stated that in microaggregates occluded light fraction contained the highest SOC concentrations (89-239 $\mathrm{g} \mathrm{kg}^{-1}$ ). It could be explained by the fact that light fraction consists mostly of floating undecomposed plant residues (Christensen, 1992; Cerli et al., 2012). In other fractions SOC concentrations decreased in the order: both occluded and not occluded silt + clay fractions (SOC concentrations - about 7-39 $\mathrm{g} \mathrm{kg}^{-1}$ ) $>$ unprotected SOC fraction of coarse sand + coarse fPOM (1-9 $\left.\mathrm{g} \mathrm{kg}^{-1}\right)$ $>$ physically protected SOC $\left(1-3 \mathrm{~g} \mathrm{~kg}^{-1}\right)$.

Table 6. The concentration of soil organic carbon $\left(\mathrm{g} \mathrm{kg}^{-1}\right)$ in the size and density fractions in surface mineral layers of studied Arenosol

\begin{tabular}{|c|c|c|c|c|c|}
\hline \multirow{3}{*}{ Land use } & \multirow{3}{*}{$\begin{array}{l}\text { Coarse sand }+ \\
\text { coarse fPOM } \\
(>250 \mu \mathrm{m})\end{array}$} & \multicolumn{3}{|c|}{ Microaggregates + fine fPOM + fine sand $(53-250 \mu \mathrm{m})$} & \multirow{3}{*}{$\begin{array}{l}\text { Silt + clay } \\
(<53 \mu \mathrm{m})\end{array}$} \\
\hline & & \multirow{2}{*}{$\begin{array}{l}\text { light fraction } \\
\text { (fine fPOM) }\end{array}$} & \multicolumn{2}{|c|}{ heavy fraction } & \\
\hline & & & $>53 \mu \mathrm{m}$ & $<53 \mu \mathrm{m}$ & \\
\hline \multicolumn{6}{|c|}{$0-10 \mathrm{~cm}$} \\
\hline Arable & $2.9 \pm 0.4$ & $138.9 \pm 11.5$ & $1.9 \pm 0.1$ & $24.8 \pm 1.3$ & $33.6 \pm 1.4$ \\
\hline Abandoned & $4.0 \pm 1.0$ & $206.9 \pm 19.8$ & $2.3 \pm 0.2$ & $24.1 \pm 1.3$ & $39.0 \pm 2.6$ \\
\hline Scots pine & $5.0 \pm 0.3$ & $133.3 \pm 7.8$ & $1.3 \pm 0.1$ & $21.0 \pm 0.9$ & $31.4 \pm 3.0$ \\
\hline Silver birch & $9.4 \pm 0.6$ & $124.4 \pm 8.9$ & $3.0 \pm 0.1$ & $38.3 \pm 1.4$ & $34.2 \pm 1.6$ \\
\hline \multicolumn{6}{|c|}{$10-20 \mathrm{~cm}$} \\
\hline Arable & $2.6 \pm 0.2$ & $144.2 \pm 12.4$ & $1.9 \pm 0.1$ & $24.7 \pm 0.6$ & $36.6 \pm 0.5$ \\
\hline Abandoned & $2.6 \pm 0.1$ & $239.2 \pm 16.5$ & $1.7 \pm 0.2$ & $20.1 \pm 0.6$ & $31.1 \pm 0.8$ \\
\hline Scots pine & $4.3 \pm 0.7$ & $128.8 \pm 11.0$ & $1.0 \pm 0.1$ & $17.6 \pm 0.4$ & $26.1 \pm 1.1$ \\
\hline Silver birch & $4.5 \pm 0.0$ & $156.6 \pm 7.8$ & $1.9 \pm 0.0$ & $25.6 \pm 2.3$ & $30.9 \pm 1.8$ \\
\hline \multicolumn{6}{|c|}{$20-40 \mathrm{~cm}$} \\
\hline Arable & $0.8 \pm 0.0$ & $155.9 \pm 4.3$ & $1.0 \pm 0.1$ & $10.0 \pm 1.1$ & $11.1 \pm 2.1$ \\
\hline Abandoned & $1.0 \pm 0.2$ & $299.7 \pm 24.6$ & $1.7 \pm 0.2$ & $7.0 \pm 0.3$ & $9.4 \pm 3.3$ \\
\hline Scots pine & $2.1 \pm 0.7$ & $89.2 \pm 0.7$ & $0.7 \pm 0.1$ & $7.7 \pm 0.3$ & $9.2 \pm 2.1$ \\
\hline Silver birch & $1.3 \pm 0.1$ & $108.2 \pm 14.5$ & $1.0 \pm 0.0$ & $9.9 \pm 0.8$ & $10.4 \pm 0.8$ \\
\hline
\end{tabular}

Explanations under Table 5 
The relative distribution of the whole SOC (expressed as $\mathrm{g} \mathrm{kg}^{-1} \mathrm{C}$ of bulk soil) over the different fractions is shown in Table 7. In general, it could be stated that the highest mean relative concentrations of SOC were in course sand + coarse PPOM fraction: from $0.5-$ $0.9 \mathrm{~g} \mathrm{~kg}^{-1}$ at $20-40 \mathrm{~cm}$ depth to $1.2-5.2 \mathrm{~g} \mathrm{~kg}^{-1}$ of bulk soil in $0-20 \mathrm{~cm}$ layer. The relative concentrations of SOC in other fractions could be ranked according to the decrease: silt + clay occluded SOC $\left(0.3-0.6 \mathrm{~g} \mathrm{~kg}^{-1}\right.$ in $20-40 \mathrm{~cm}$ and $0.6-2.4 \mathrm{~g} \mathrm{~kg}^{-1}$ of bulk soil in $0-20 \mathrm{~cm}$ layer) $\geq \mathrm{SOC}$ in light fraction $=$ silt + clay not occluded SOC (both from $0.1-0.4$ to $\left.0.6-2.3 \mathrm{~g} \mathrm{~kg}^{-1}\right)>$ in microaggregates physically protected SOC $\left(0.3-1.0 \mathrm{~g} \mathrm{~kg}^{-1}\right.$ of bulk soil DM).

Table 7. The distribution of total soil organic carbon over the different fractions (calculated as $\mathrm{g} \mathrm{kg}^{-1} \mathrm{C}$ whole/bulk mineral soil) of studied Arenosol

\begin{tabular}{|c|c|c|c|c|c|}
\hline \multirow{3}{*}{ Land use } & \multirow{3}{*}{$\begin{array}{c}\text { Coarse sand }+ \\
\text { coarse fPOM } \\
(>250 \mu \mathrm{m})\end{array}$} & \multicolumn{3}{|c|}{ Microaggregates + fine fPOM + fine sand $(53-250 \mu \mathrm{m})$} & \multirow{3}{*}{$\begin{array}{l}\text { Silt }+ \text { clay } \\
(<53 \mu \mathrm{m})\end{array}$} \\
\hline & & \multirow{2}{*}{$\begin{array}{l}\text { light fraction } \\
\text { (fine fPOM) }\end{array}$} & \multicolumn{2}{|c|}{ heavy fraction } & \\
\hline & & & $>53 \mu \mathrm{m}$ & $<53 \mu \mathrm{m}$ & \\
\hline \multicolumn{6}{|c|}{$0-10 \mathrm{~cm}$} \\
\hline Arable & $1.6 \pm 0.3$ & $0.6 \pm 0.2$ & $0.6 \pm 0.1$ & $2.1 \pm 0.9$ & $1.3 \pm 0.2$ \\
\hline Abandoned & $1.8 \pm 0.7$ & $1.7 \pm 0.3$ & $1.0 \pm 0.2$ & $1.0 \pm 0.5$ & $1.1 \pm 0.2$ \\
\hline Scots pine & $2.3 \pm 0.2$ & $2.3 \pm 0.2$ & $0.5 \pm 0.2$ & $1.3 \pm 0.5$ & $1.8 \pm 0.3$ \\
\hline Silver birch & $5.2 \pm 0.8$ & $0.8 \pm 0.2$ & $1.0 \pm 0.1$ & $2.4 \pm 0.5$ & $2.2 \pm 0.4$ \\
\hline \multicolumn{6}{|c|}{$10-20 \mathrm{~cm}$} \\
\hline Arable & $1.4 \pm 0.1$ & $0.6 \pm 0.1$ & $0.6 \pm 0.0$ & $2.1 \pm 0.3$ & $1.4 \pm 0.1$ \\
\hline Abandoned & $1.2 \pm 0.1$ & $1.1 \pm 0.2$ & $0.7 \pm 0.1$ & $1.1 \pm 0.1$ & $1.2 \pm 0.2$ \\
\hline Scots pine & $2.1 \pm 0.5$ & $0.9 \pm 0.2$ & $0.5 \pm 0.1$ & $0.6 \pm 0.5$ & $1.3 \pm 0.2$ \\
\hline Silver birch & $2.3 \pm 0.1$ & $0.2 \pm 0.1$ & $0.7 \pm 0.0$ & $2.1 \pm 0.7$ & $1.8 \pm 0.2$ \\
\hline \multicolumn{6}{|c|}{$20-40 \mathrm{~cm}$} \\
\hline Arable & $0.5 \pm 0.1$ & $0.2 \pm 0.0$ & $0.3 \pm 0.1$ & $0.5 \pm 0.2$ & $0.2 \pm 0.1$ \\
\hline Abandoned & $0.5 \pm 0.2$ & $0.3 \pm 0.0$ & $0.6 \pm 0.2$ & $0.3 \pm 0.1$ & $0.1 \pm 0.1$ \\
\hline Scots pine & $0.9 \pm 0.5$ & $0.3 \pm 0.0$ & $0.3 \pm 0.1$ & $0.5 \pm 0.1$ & $0.4 \pm 0.2$ \\
\hline Silver birch & $0.7 \pm 0.1$ & $0.1 \pm 0.0$ & $0.4 \pm 0.0$ & $0.6 \pm 0.1$ & $0.4 \pm 0.1$ \\
\hline
\end{tabular}

Explanations under Table 5

In summary, total SOC was mainly accommodated in unprotected $(>250 \mu \mathrm{m})$ fPOM (in average $32 \%$ ) and in SOM occluded $(23 \%)$ and not occluded $(20 \%)$ in silt + clay fractions. Meanwhile, light fraction and physically protected SOM in 53-250 $\mu \mathrm{m}$ sized microaggregates amounted to $14 \%$ and $11 \%$ of total $\mathrm{SOC}$ in bulk soil, respectively. Significant differences in the distribution of total SOC concentrations between the fractions were mainly detected only between present and former Ap horizons (0-10 and 10-20 cm mineral layers) (Table 7). In pine and birch plantations, former Ap horizons contained on average 1.7-2.2 times more of unprotected SOC and 1.4-1.8 times more SOC in silt + clay not occluded SOM than present/former Ap horizons in arable and abandoned arable land. In both cases the highest mentioned concentrations were found in birch plantations. Moreover, in birch plantation at the $10-20 \mathrm{~cm}$ depth there were detected the lowest concentrations of SOC unprotected in light fraction of microaggregates, while in pine plantations - in opposite, the highest concentrations.

Our data confirmed, as Six et al. (2002) did, that silt + clay protected SOC was reduced by the cultivation of arable land. Moreover, such loss of protected SOC remained in abandoned arable land as well.

Chemically and biochemically protected SOC. The analyzed samples of studied sandy Arenosol had very low content of silt + clay $(<53 \mu \mathrm{m})$ sized soil fraction after the acid hydrolysis. However, it could be stated (Fig. 2) that the mean concentrations of chemically stabilized/ protected SOC varied from $8.5-10.3 \mathrm{~g} \mathrm{~kg}^{-1}$ (at $20-40 \mathrm{~cm}$ depth) to $24.6-35.4 \mathrm{~g} \mathrm{~kg}^{-1}(0-20 \mathrm{~cm})$ and were similar to SOC concentrations in SOM that was not occluded in silt + clay fraction (Table 6). Whereas the concentrations of biochemically stabilized SOC were at the same level or 1.4 1.8 times lower compared to chemically stabilized SOC.
Hydrolyzable SOC

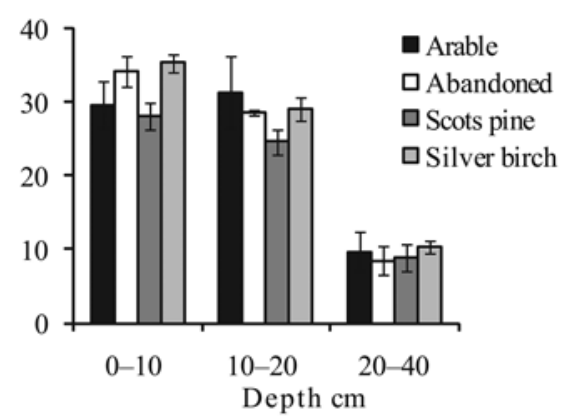

Non-hydrolyzable SOC

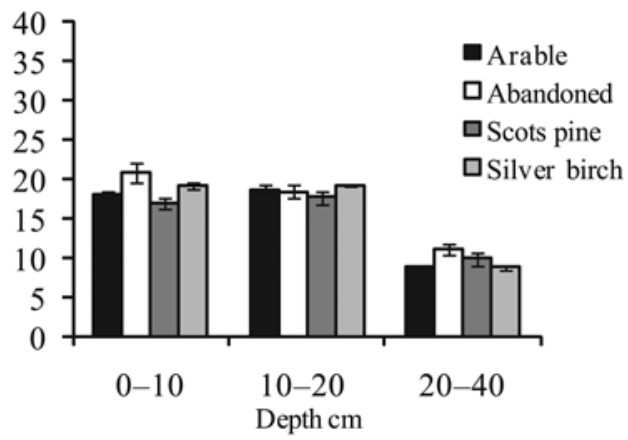

Figure 2. Mean concentrations $\left(\mathrm{g} \mathrm{kg}^{-1}\right)$ of hydrolyzable and non-hydrolyzable soil organic carbon (SOC) in the silt + clay $(<53 \mu \mathrm{m})$ sized mineral soil fraction in the different land use of Arenosol (the bars on the columns indicate SD of the means) 
The concentrations of hydrolyzable and nonhydrolyzable SOC varied among different land uses insignificantly. It could be explained by very slow turnover time of chemically and biochemically protected SOC (Six et al., 2002; von Lützow et al., 2007; Guggenberger, 2010). However, it could be explained that both concentrations of hydrolyzable and non-hydrolyzable SOC tended to be the lowest in former Ap horizon in pine plantations (Fig. 2). Meanwhile, such concentrations in birch plantations were at the same level or higher than in arable land.

\section{Conclusions}

1. Low contents of soil microbial biomass carbon $\left(\mathrm{C}_{\text {bio }}\right)$ indicated that soil organic matter $(\mathrm{SOM})$ was intensively decomposing by microbiota of sandy Arenosol $(A R)$ within three different land uses: continuous arable land, abandoned arable land, and afforested with Scots pine or silver birch land. However, mean $\mathrm{C}_{\text {bio }}$ was the lowest in pine plantations, the highest in birch plantations and intermediate in arable or abandoned arable land.

2. Chemically as well as biochemically protected soil organic carbon (SOC) did not very significantly in the studied land uses. Whereas unprotected and physically protected SOC significantly differed mainly in the $0-10 \mathrm{~cm}$ mineral topsoil. The highest concentrations of fulvic and humic acids and unprotected water extractable SOC were found in forest plantations. However, mineral topsoil after the afforestation, especially with birch, contained the highest concentrations of total SOC and the concentrations of SOC protected in SOM of silt + clay sized $(<53 \mu \mathrm{m})$ fraction.

3 . The obtained results confirmed the Kyoto Protocol's provision that the afforestation of nutrientpoor sandy arable soils with birch in Lithuania could be relevant, with the focus on carbon sequestration.

\section{Acknowledgements}

This research was funded by a grant (No. MIP038/2011) from the Research Council of Lithuania. We are grateful to Milda Viltrakyte for providing technical assistance.

Received 06022012 Accepted 18072013

\section{References}

Anderson J. P. E., Domsch K. H. 1989. Ratios of microbial biomass carbon to total organic carbon in arable soils. Soil Biology and Biochemistry, 21: 471-479 http://dx.doi.org/10.1016/0038-0717(89)90117-X

Armolaitis K., Aleinikovienè J., Baniūnienè A., Lubytė J., Žèkaitè V. 2007. Carbon sequestration and nitrogen status in Arenosols following afforestation or following abandonment of arable land. Baltic Forestry, 1 (14): 169-178

Armolaitis K., Žèkaitė V., Aleinikovienė J., Česnulevičienė R. 2011. Renaturalization of Arenosols in the land afforested with Scots pine (Pinus sylvestris L.) and abandoned arable land. Zemdirbyste-Agriculture, 98 (3): 275-282

Bauhus J. D., Pare D., Côte L. 1998. Effects of tree species, stand age and soil type on soil microbial biomass and its activity in a southern boreal forest. Soil Biology and Biochemistry, 30: $1077-1089$ http://dx.doi.org/10.1016/S0038-0717(97)00213-7
Brookes P. C., Kragt J. F., Powlson D. S., Jenkinson D. S. 1985. Chloroform fumigation and the release of soil nitrogen: the effects of fumigation time and temperature. Soil Biology and Biochemistry, 17: 831-835 http://dx.doi.org/10.1016/0038-0717(85)90143-9

Cerli C., Celi L., Kalbitz K., Guggenberger G., Kaiser K. 2012. Separation of light and heavy organic matter fractions in soil - testing for proper density cut-off and dispersion level. Geoderma, 170: 403-416 http://dx.doi.org/10.1016/j.geoderma.2011.10.009

Christensen B. T. 1992. Physical fractionation of soil and organic matter in primary particle size and density separates. Advise and Soil Science, 20: 1-89 http://dx.doi.org/10.1007/978-1-4612-2930-8 1

Diaz-Ravina M., Caraballas T., Acea M. J. 1988. Microbial biomass and activity in four acid soils. Soil Biology and Biochemistry, 20: 817-823 http://dx.doi.org/10.1016/0038-0717(88)90087-9

Ellerbrock R. H., Gerke H. H., Bachmann J., Goebel M. O. 2005. Composition of organic matter fractions for explaining wettability of three forest soils. Soil Science Society of America Journal, 69: 57-66 http://dx.doi.org/10.2136/sssaj2005.0057

Faithfull N. T. 2002. Method 5.4. Determination of fulvic and humic acids. Methods of Agricultural Chemical Analysis: a Practical Handbook, p. 68-71

FAO/UN. 2006. World Reference Base for Soil Resources 2006. $<\mathrm{ftp}: / / \mathrm{ftp}$.fao.org/agl/agll/docs/wsrr103e.pdf $>$ [accessed 2802 2013]

Feiziene D., Feiza V., Slepetiene A., Liaudanskiene I., Kadziene G., Deveikyte I., Vaideliene A. 2011. Long-term influence of tillage and fertilization on net carbon dioxide exchange rate on two soils with different textures. Journal of Environmental Quality, 40: 1787-1796 http://dx.doi.org/10.2134/jeq2011.0180

Franzmeier D. P., Lemme G. D., Miles R. J. 1985. Organic carbon in soils of North Central United States. Soil Science Society of American Journal, 49: 702-708 http://dx.doi. org/10.2136/sssaj1985.03615995004900030035x

Guggenberger G. 2010. Soil organic carbon pools, fractions and stabilization mechanisms. Brunner I. (ed.). Belowground carbon turnover in European forests - State of the Art: COST Action FP0803 Conference. Birmensdorf, Switzerland, p. 31-33

IPCC. 2003. Good Practice Guidance for Land Use. LandUse Change and Forestry (IPCC GPG LULUCF). <http:// www.ipcc-nggip.iges.or.jp/public/gpglulucf/gpglulucf. $\mathrm{htm}>$ [accessed 2802 2013]

IPCC. 2006. 2006 IPCC Guidelines for National Greenhouse Gas Inventories. Intergovernmental Panel on Climate Change. $<$ http://www.ipcc-nggip.iges.or.jp/public/2006gl/ index.htm $>$ [accessed 2802 2013]

IPCC. 2007. Climate Change 2007: Impacts, Adaptation and Vulnerability. Summary for Policymakers. Intergovernmental Panel on Climate Change. $<$ http://www. ipcc.ch/SPM13apr07.pdf $>$ [accessed 2802 2013]

Kalbitz K., Schmerwitz J., Schwesig D., Matzner E. 2003. Biodegradation of soil-derived dissolved organic matter as related to its properties. Geoderma, 113: 273-291 http://dx.doi.org/10.1016/S0016-7061(02)00365-8

Lal R. 2009. Challenges and opportunities in soil organic matter research. European Journal of Soil Science, 60: 158-169 http://dx.doi.org/10.1111/j.1365-2389.2008.01114. x

Liaudanskienė I., Ślepetienè A., Velykis A. 2011. Changes in soil humified carbon content as influenced by tillage and crop rotation. Zemdirbyste-Agriculture, 98 (2): 227-234

Scharenbroch B. C., Lloyd J. E., Johnson-Maynard J. L. 2005. Distinguishing urban soils with physical, chemical, and biological properties. Pedobiologia, 49: 283-296 http://dx.doi.org/10.1016/j.pedobi.2004.12.002 
Schimel D. S., Braswell B. H., Holland E. A., McKeown R., Ojima D. S., Painter T. T., Parton W. J., Townsend A. R. 1994. Climatic, edaphic and biotic controls over storage and turnover of carbon in soils. Global Biogeochemistry, 8: 279-293 http://dx.doi.org/10.1029/94GB00993

Schulz E., Deller B., Hoffmann G. 1991. Methoden Buch I.

Six J., Conant R. T., Paul E. A., Paustian K. 2002. Stabilization mechanisms of soil organic matter: implications for C-saturation of soils. Plant and Soil. 241 (2): 155-176 http://dx.doi.org/10.1023/A:1016125726789

Sleutel S., De Neve S., Németh T., Tóth T., Hofman G. 2006. Effect of manure and fertilizer application on the distribution of organic carbon in different soil fractions in long-term field experiments. European Journal of Agronomy, 25: 280-288 http://dx.doi.org/10.1016/j.eja.2006.06.005

Šlepetienè A., Slepetys J., Liaudanskienè I., Maryganova V., Kavoliūte F., Kinderienè I. 2008. The effect of land use on the soil carbon, total and extractable SOM. Žemès ūkio mokslai, 15 (3): 42-46
UNFCC. 1998. Kyoto Protocol to the United Nations Framework Convention on Climate Change

Vaičys M., Raguotis A., Armolaitis K., Kubertavičienė L. 1997. Forest pedology. Lietuvos mokslas, V (13-14): 237-256 (in Lithuanian)

Vance E. D., Brookes P. C., Jenkinson D. S. 1987. An extraction method for measuring soil microbial biomass C. Soil Biology and Biochemistry, 19: 703-707 http://dx.doi.org/10.1016/0038-0717(87)90052-6

von Lützow M., Kögel-Knabner I., Ekschmitt K., Flessa H., Guggenberger G., Matzner E., Marschner B. 2007. SOM fractionation methods: relevance to functional pools and to stabilization mechanisms. Soil Biology and Biochemistry, 39 (9): 2183-2207

http://dx.doi.org/10.1016/j.soilbio.2007.03.007

ISSN 1392-3196 / e-ISSN 2335-8947

Zemdirbyste-Agriculture, vol. 100, No. 3 (2013), p. 227-234

DOI 10.13080/z-a.2013.100.029

\title{
Dirvožemio organinès anglies tvarumas smèlžemio (Arenosol) žemès ūkio ir miško ekosistemose
}

\author{
K. Armolaitis ${ }^{1,2}$, J. Aleinikovienè $\dot{1}^{1}$ J. Lubytė ${ }^{3}$, V. Žèkaitè ${ }^{2}$, P. Garbaravičius ${ }^{1}$ \\ ${ }^{1}$ Lietuvos agrarinių ir miškų mokslų centro Miškų institutas \\ ${ }^{2}$ Lietuvos agrarinių ir miškų mokslų centro Perlojos bandymų stotis \\ ${ }^{3}$ Lietuvos agrarinių ir miškų mokslų centro Agrocheminių tyrimų laboratorija
}

\section{Santrauka}

Tyrimų tikslas - įvertinti smèlžemio (SD) organinės anglies (C) tvarumą taikant skirtingą žemėnaudą: 1) nuolat ariamoje žemèje, 2) 15 metų dirvonuojančioje žemëje ir 3) prieš 50 metų paprastosios pušies (Pinus sylvestris L.) arba karpotojo beržo (Betula pendula Roth) želdiniais apželdintoje žemejje. Dirvožemio 0-10, 10-20 ir 20-40 cm mineraliniuose sluoksniuose nustatyta: 1) suminè dirvožemio organiné anglis (DOA) ir humuso frakcinè sudètis, 2) aktyvioji DOA (vandenyje tirpi DOA ir C dirvožemio mikrobiotos biomasèje), 3) mineralinio dirvožemio skirtingose frakcijose nuo mikrobiologinio skaidymo neapsaugota aktyvioji ir apsaugota skirtingo tvarumo DOA. Mažiausios C koncentracijos dirvožemio mikrobiotos biomasėje buvo pušų želdynuose, didžiausios - beržyne, o ariamoje ir dirvonuojančioje žemėse užèmė tarpinę vietą. Huminių bei fulvinių rūgščių ir aktyviosios vandenyje tirpios DOA didžiausios koncentracijos buvo mišku apželdintoje buvusioje ariamoje žemėje. Tačiau po apželdinimo, ypač beržais, dirvožemio viršutiniame mineraliniame sluoksnyje padidèjo suminès DOA koncentracija ir DOA koncentracija DOM, kuri apsaugota dumblo + molio $(<53 \mu \mathrm{m})$ frakcijos.

Tyrimų duomenys patvirtino Kioto protokolo nuostatą, kad nederlingus smėlžemius, siekiant juose kaupti SOC, tikslinga apželdinti beržais.

Reikšminiai žodžiai: aktyvioji ir tvari DOA, ariama žemė, dirvonuojanti žemè, mišku apželdinta žemè. 